\title{
Y Kuşağı Stajyer Öğrencilerin X Kuşağı Çalışan Hemşirelere Yönelik Görüşleri: Kalitatif Bir Yaklaşım
}

\author{
Sibel Şentürk*1 ${ }^{1}$ Berna Karahan ${ }^{2}$ \\ ${ }^{1}$ Mehmet Akif Ersoy Üniversitesi Bucak Sağlık Yüksekokulu İç Hastalıkları Hemşireliği Burdur, Türkiye \\ ${ }^{2}$ Mehmet Akif Ersoy Üniversitesi Bucak Sağlık Yüksekokulu Burdur, Türkiye \\ email: sibelsenturk@mehmetakif.edu.tr, bernakarahan31@gmail.com \\ Orcid: 0000-0002-5634-174X \\ Orcid: 0000-0003-4114-3270 \\ *Sorumlu Yazar / Corresponding Author: Sorumlu Yazar: Sibel Şentürk
}

Gönderim Tarihi / Received: 14.02.2019

Kabul Tarihi / Accepted: 08.08.2019

DOI: $10.34087 /$ cbusbed.527175

\section{Öz}

Amaç: $\mathrm{Bu}$ araştırma, Y kuşağı stajyer öğrencilerin $\mathrm{X}$ kuşağı çalışan hemşirelere yönelik görüşlerini belirlemek amacıyla yapılmıştır.

Gereç ve Yöntem: Bu araştırma, hemşirelik üçüncü ve dördüncü sınıfta eğitimlerine devam eden ve çalışmaya katılmayı kabul eden toplam 10 öğrenci ile yapılmıştır. Y kuşağı stajyer öğrencilerin X kuşağ çalışan hemşirelere yönelik duygu ve düşünceleri nitel yöntem ile aktarılmıştır. Veriler, yarı yapılandırılmış görüşme formu ile yüz yüze görüşülerek 25-30 dakikada toplanmıştır. Görüşmeler sırasında öğrencilerin ifadeleri ses kayıt cihazı ile kaydedilmiş ve gerekli yerlerde notlar alınmıştır. Öğrencilerin duygularını daha iyi anlatabilmeleri için ayrıca yazılı olarak da duygu ve düşüncelerini aktarmaları istenmiştir. Verilerin değerlendirilmesinde içerik analizi yöntemi kullanılmış olup yapılan kodlamalar sonucunda 8 tema belirlenmiştir.

Bulgular: Çalışmaya katılan Y kuşağı stajyer öğrencilerin büyük çoğunluğu X kuşağı hemşirelerin kısmen rol modeli olduğunu, hastayla etkin olmasa da bir iletişim kurduklarını ancak bazılarının öğrencileri sürekli azarlayarak konuştuğunu, teknik becerilerinin iyi olduğunu, bilimsel bilgiyi ve kongreleri takip etmediklerini, sorumluluk bilinçlerinin ve eğitim becerilerinin yüksek olduğunu, teknolojiyi kullanmada yetersiz olduklarını ve etik değerlere uygun davranmaya çalıştıklarını ifade etmişlerdir.

Sonuç: Çalışmanın sonucunda, Y kuşağı stajyer öğrencilerin X kuşağı hemşirelere karşı genel anlamda olumlu düşüncelerinin olduğu ancak özellikle yenilikleri takip etme, kongrelere gitme ve iletişim konularında yetersiz gördükleri tespit edilmiştir.

Anahtar Kelimeler: Y kuşağı, X kuşağı, Stajyer öğrenci, Hemşire, Kalitatif Çalışma.

Abstract
Objective: This research was conducted in order to determine the opinions of the Generation Y intern students
about the working nurses from the Generation X.
Methods: This research was conducted with 10 students who are continuing their studies in the $3^{\text {rd }}$ and $4^{\text {th }}$ grade and
have accepted to participate in the research. The thoughts and feelings of the Generation Y intern students about the
Generation X working nurses is narrated via a qualitative method. With the use of a semi-structured interview form,
the data was obtained within $25-30$ minutes via a face-to-face interview. During the interviews the expressions of
the students were recorded via a voice recorder and notes were taken when it was necessary. The students were
asked to narrate their thoughts and feelings in a written method as well, for that would enable them to express their
sentiments better. The method of content analysis was used for the evaluation of the data and 8 themes were
determined as a result of the codings that were made.
Results: A great deal of Generation Y intern students who have participated in the researched have expressed that
Generation X nurses were, partially, role models, they have expressed that they communicate with the patient but
some of them always talk to the students with a reprimanding tone and while their technical abilities are good they
do not follow scientific knowledge and congresses and they are inadequate regarding the use of technology but try to
behave accordingly to ethical values.


Conclusion: As the conclusion of the research, it was determined that Generation $\mathrm{Y}$ intern students generally have positive thoughts regarding Generation X nurses yet Generation X nurses were seen as inadequate regarding the subjects such as following innovations, congresses and communication.

Key words: Y generation, X generation, Intern student, Nurse, Qualitative Study.

\section{Giris}

Türk Dil Kurumu (TDK)'na göre kuşak; aşağı yukarı aynı yıllarda doğmuş olup, aynı çağın koşullarını, dolayısıyla birbirine benzer sıkıntıları yaşamış, benzer ödevlerle yükümlü olmuş kişiler topluluğu olarak tanımlanmakta olup [1], günümüzde sessiz/savaş kuşağ1, büyük bebek patlaması, X, Y ve Z kuşağı olmak üzere 5 kuşak olduğu ifade edilmektedir [2]. Çalışma yaşamı içinde birbirleriyle etkileşim halinde bulunan bu kuşaklar; kendinden öncekileri çağdışı, muhafazakâr, değişime dirençli, anlayışsız olarak değerlendirirken, kendinden sonra gelen kuşağı ise sorumluluk hissetmeyen ve saygısını yitirmiş kişiler olarak nitelendirmektedir [3]. Genel olarak kuşaklar arasında belirli farklılıklar olduğu ve bu farklılıkların kompleks ve hizmet çıktısı insan olan sağlık sektöründe sorunlara yol açtı̆̆ 1 ifade edilmektedir. Bu sorunların önüne geçebilmek adına çalışma ortamında birbirleriyle etkileşim halinde olan bireylerin birbirlerinin kuşak özelliklerini bilmesi ve ona göre bir anlayış geliştirmesi gerekmektedir [4].

Günümüzde sağlık sektörüne bakıldığında sayısal çoğunluğu oluşturan meslek grubu olarak hemşirelerin arasında da kuşak farklılıkları olduğu bilinmektedir [4]. Amerika'da yapılan çalışmalarda 5 kuşağında aktif olarak sağlık sektöründe hizmet verdiği bildirilmektedir [5]. Önümüzdeki yıllarda bu durumla ülkemizdeki sağlık sektöründe de karşılaşılmasının kaçınılmaz olacağ1 ifade edilmektedir [6]. İş dünyasında en yoğun nüfusa sahip kuşağın $X$ kuşağı olduğu ve hemen ardından yoğunluğun $\mathrm{Y}$ kuşağında olduğu bildirilmektedir [7]. 1965-1978 yılları arasında doğan ve bugünlerde 41-54 yaş aralığında olan bireyler olarak tariflenen X kuşağının özelliklerine bakıldığında; iş yaşamında sadık, kanaat duyguları yüksek, aynı işte uzun yıllar çalışmış, toplumsal sorunlara karşı duyarlı, iş motivasyonları yüksek, otoriteye saygılı bireyler olduğu görülmektedir. 1981-2000 yılları arasında doğan ve 'Internet Kuşağı' olarak da isimlendirilen Y kuşağının özelliklerine bakıldığında ise; her şeyi elde edebileceğine inanan, modern teknolojiler ve tüketim ile büyümüş, deneyimli, bilgili, hırslı, iş yaşamında hızlı yükselmeyi arzulayan, yaşamına hayat boyu öğrenme kavramını entegre eden, rol modellerine ihtiyaç duyan, takdir edilmek ve güdülenmek isteyen bireyler olduğu görülmektedir [2,5]. İş yaşamında en yoğun popülasyona sahip olan X kuşağı ve Y kuşağının farklı özelliklerinin de olduğu bilinmesine rağmen birbirine yakın doğan bireylerinde benzer motivasyon ve değerleri paylaştığ 1 düşünülmektedir [8]. Fakat kuşakların birbirlerini nasıl gördüğü son yıllarda merak konusu olmuştur. Literatürde, $\mathrm{X}$ kuşağı çalışan hemşirelerin staja çıkan Y kuşağı hakkındaki görüşlerine yönelik çalışmalar olmasına karşın, Türkiye'de Y kuşağı stajyer öğrencilerin staja çıktıkları kliniklerdeki X kuşağı çalışan hemşirelerin mesleki uygulamaları, hasta-hemşire iletişimi, etik değerlere duyarlılık gibi konulara ilişkin görüşlerini ifade ettikleri bir çalışmaya rastlanmamıştır. Türkiye'de kuşaklararası farklılıkların hemşirelik mesleğine etkisini belirlemek üzere yapılan ilk çalışmalardan biri olan araştırmanın ilerde uzun yıllar beraber çalışacak olan farklı kuşakların birbirini nasıl gördüğü ile ilgili önemli bir eksiği gidermesi yönüyle literatüre 1 şı tutacağ 1 düşünülmektedir.

Amaç: $\mathrm{Bu}$ araştırma, henüz iş yaşamına girmemiş $\mathrm{Y}$ kuşağı stajyer öğrencilerin X kuşağı çalışan hemşirelere yönelik görüşlerini belirlemek amacıyla yapılmıştır.

\section{Gereç ve Yöntem}

2.1 Araştırmanın tipi: Araştırma, betimsel veri analizine dayalı niteliksel bir araştırma olarak planlanmıştır.

2.2Araştırmanın evren ve örneklemi: $\mathrm{Bu}$ araştırmanın evrenini 2016-2017 eğitim-öğretim yılında Mehmet Akif Ersoy Üniversitesi Sağlık Bilimleri Fakültesi hemşirelik bölümünde eğitimine devan eden öğrenciler oluşturmuştur. Niteliksel araştırmalarda örneklem sayısı ile ilgili herhangi bir kural belirlenmemiş olup, derinlemesine görüşmelerin yapıldığı niteliksel çalışmalarda 5 ila 25 katılımcı ile sınırlı küçük sayıda örneklem grupları ile yapılmaktadır [9]. Bununla birlikte araştırmanın örneklemine alınan katılımcıların sorulara verdikleri cevaplar birbirine benzer olmaya başlayınca araştırmanın doyum noktasına ulaştığ bilinmektedir ve veri toplama işlemi durdurulmaktadır [10]. Bu nedenle çalışmanın örneklemini 2016-2017 eğitim öğretim yılı bahar döneminde üçüncü ve dördüncü sınıfta olup öğrenimlerine devam eden, hemşirelik ile ilgili dersler nedeniyle farklı kliniklerde saha uygulamasına çıkan ve çalışmaya katılmayı kabul eden toplam 10 öğrenci oluşturmuştur. Örneklemin belirlenmesinde, daha fazla sayıda ve çeşitte veri elde etmek için amaçlı örnekleme yöntemlerinden maksimum çeşitleme yöntemi kullanılarak 3.ncü sinıftan 5 öğrenci, 4.ncü sınıftan 5 öğrenci olmak üzere kız ve erkek sayıları eşit alınmıştır.

2.3Veri Toplama Formu: $\mathrm{Bu}$ çalışmada veriler, araştırmacılar tarafından literatür taranarak hazırlanan $\mathrm{X}$ kuşağı çalışan hemşirelerin özelliklerini irdeleyen yarı yapılandırılmış görüşme formu ile toplanmıştır.

Görüşme formunun ilk bölümünde öğrencilerin yaş, cinsiyet, sınıf, staja çıktığı klinikler ve staj uygulamalarında klinikteki hemşirelere göre kendilerini üstün gördükleri yönleri ile ilgili bilgileri yer almıştır. 
Diğer bölümünde ise öğrencilerin X kuşağı hemşirelerin klinik uygulamalarda öğrencilere ve hastalara bakım verirken sergiledikleri mesleki yaklaşımları belirlemek için yönlendirici olmayan, geneli kapsayan 3 adet açık uçlu soru yöneltilmiştir. Çalışmada öğrencilere yöneltilen açık uçlu sorular ' $\mathrm{Y}$ kuşağı stajyer hemşireler olarak almış olduğunuz hemşirelik eğitimine göre değerlendirdiğinizde staj uygulamalarınızda karşılaştığınız X kuşağı hemşire profili/profilleri ile ilgili olarak neler söylersiniz?', 'Mesleki açıdan değerlendirdiğinizde Staj uygulamalarınız sırasında X kuşağı hemşirelerle yaşamış olduğunuz olumlu ve olumsuz staj deneyimlerinizi paylaşır mısınız?', 'Y kuşağı stajyer hemşireler olarak X kuşağı çalışan hemşirelerden staj uygulamaları sırasındaki beklentileriniz nelerdir?' şeklinde sıralanmıştır.

2.4 Verilerin Toplanması: Veriler, yüz yüze görüşme yöntemi kullanılarak yarı yapılandı $\neg$ rılmış soru formu aracılığıyla çeşitli derinlemesine bireysel görüşme yapılarak toplanmıştır. Görüşmeler, 6-10 Mart 2017 tarihleri arasında, öğrenci hemşirelerin okulda olduğu zamanlarda ve ders saatleri dışında yapılmıştır.

Görüşmelerin sağlıklı bir şekilde yürütülmesi için görüşmeyi yapan araştırmacıya tahsis edilen odada görüşmeler bir araştırmacı ve öğrenci ile ortalama 25-30 dakika arasında gerçekleştirilmiştir. Görüşme sırasında öğrencilerin ifadeleri ses kayıt cihazı ile kaydedilmiş ve gerekli yerlerde notlar alınmıştır. Öğrencilerin duygularını daha iyi anlatabilmeleri için ayrıca yazılı olarak da duygu ve düşüncelerini aktarmaları istenmiştir.

2.5 Etik İzinler: Araştırmanın yapılabilmesi için Mehmet Akif Ersoy Üniversitesi Girişimsel Olmayan Klinik Araştırmalar Etik kurulundan etik kurul izni (2017/64) ve araştırmanın yapıldığı okul yönetiminden de yazılı izin alınmıştır. Ayrıca araştırmaya katılan öğrencilerden de sözlü ve yazılı onam alınmış, ses kayıt cihazının kullanılacağı hakkında bilgilendirme yapılmış ve ses kaydının gizliliği konusunda da güvence verilmiştir.

2.6 Verilerin Değerlendirilmesi: Araştırmanın veri analizi, betimleme, analiz ve yorumlama olmak üzere üç aşamada gerçekleştirilmiştir. Yapılan tüm görüşmelerin ses kayıtları ve öğrencilerin yazılı olarak vermiş olduğu beyanlar manuel olarak deşifre edilmiştir. Veriler NVivo8 programı kullanılarak kodlanmıştır. Yapılan kodlamalar siniflandirılarak rol modeli olma, etkin iletişim, teknik beceri, bilimsel bilgiyi ve kongreleri takip etme, sorumluluk bilinci, eğitim becerisi, teknolojiyi kullanma ve etik davranış başlığı altında sekiz ayrı tema elde edilmiştir.

2.7 Araştırmanın Sınırlılıkları: Çalışma, nitel araştırma tekniği ile yapılması nedeniyle elde edilen bulgular sadece araştırmaya katılan 10 öğrenci görüşü ile sinırlı olup, genellenemez.

\section{Bulgular}

Bu çalışmaya katılan öğrencilerin büyük çoğunluğu kız, SML mezunu, dahili ve cerrahi kliniklerde staja çıkmış ve bölümü isteyerek gelmiştir.

\subsection{Tema: Rol Modeli Olma}

Çalışmaya katılan öğrencilerin çoğunluğu (\%60) hemşirelerin staj uygulamaları sırasında rol model olmaya çalıştıklarını, uygulamalar sırasında yardım ettiklerini, teorik bilgilerini paylaştıklarını ifade etmişlerdir.

- İş disiplini, hijyene dikkat etme, hastalara sevgiyle yaklaşma, işine her gün severek gelmelerini örnek alıyorum (23y, K, 4.ncü sınıf, Anadolu Lisesi)

- Lise mezunu bir hemşire vardı, üniversiteye gidememiş ancak teorik bilgisi epeyce yüksekti. Öğretme gücü de yeterliydi. Kendisi lise mezunu damgası yememek için yenilikleri de takip ederek açıklarını hep kapatmış. İyi bir rol model örneğiydi (21y, K, 4.ncü sınıf, Düz lise)

- İyi rol model oluyorlar ( 21y, K, 3.ncü sınıf, Düz lise).

Çalışmaya katılan öğrencilerin bir kısmı ise (\%40) herhangi bir yanlış da öğrencilere sürekli bağırdıklarını, uygulamalar sırasında başlarında gelmediklerini ve hemşirelerin cinsiyet ayrımcılığı yaparak erkek ögrencilere uygulama yaptırmak istemediklerini ifade etmişlerdir.

- Yanlışlara sürekli bağırıyorlar ancak doğruları öğretmek zor geliyor. Bağırmak yerine kibarca uyarabilirler. Bu şekilde de öğrenebiliriz ( $21 \mathrm{y}, \mathrm{K}$, 3.ncü sinif, SML).

- Erkek hemşireye karşı cinsiyet ayrımı yapılıyor, kadın-doğum stajındayken bizi erkek olduğumuz için doğumhaneye almak istemediler, sanki bu meslekte ne işiniz var gibi bir tavırları vardı, bize böyle davranan kişilerin rol modeli olabileceklerini sanmiyorum (21y, E, 4.ncü sınıf, Anadolu Lisesi)

\subsection{Tema: Etkin İletişim}

Çalışmaya katılan öğrencilerin \%80'inin hasta-hemşire, stajyer öğrenci- hemşire arasında etkin bir iletişim kurmadıklarını, sürekli azarlayarak konuştuklarını, hastalarla etkin olmasa da bir iletişim kurduklarını ancak öğrencilere karşı sert bir tavır içerisinde olduklarını ifade etmişlerdir.

- Hastayla iletişim kurmasına kuruyorlar ama bizimle sürekli azarlayıcı bir dille konuşuyorlar(21y, K,3.ncü sınıf, Düz lise).

- Bizlere karşı gerçek hemşire değilmişiz gibi davranılıyor. Buna üzülüyorum ancak sahada çalışma yapmadan bu mesleğin yapılmayacağını kendileri de bildiği halde bize olan gerekli saygıyı çoğu zaman gösteremiyorlar (23y, K, 4.ncü sınıf, Anadolu Lisesi)

- Her şeyi kızlarla paylaşıyorlar, hemşire odasında oturmamızdan rahatsız oluyorlar. Erkeklere karşı ayrımcılık var (21y, E, 4.ncü sınıf, Anadolu Lisesi)

- Etkin iletişim profesyonelliğin yanı sıra, genel kültür ve iletişim becerilerine dayanır. Bu sebepten dolayı X kuşağı bazı durumlarda, ne kadar profesyonel olsa da iletişim kopuklukları 
gözlenebilmektedir. Örneğin önceki staj yaptığım kurumda hemşirenin yöresel ağız kullanması sebebiyle iletişimimizde sıkıntı yaşanmıştı $(25 \mathrm{y}, \mathrm{E}$, 4.ncü sınıf, SML).

\subsection{Tema: Teknik Beceri}

Çalışmaya katılan öğrencilerin \%90’1 X kuşağı hemşirelerin yılların verdiği deneyim nedeniyle teknik becerilerinin iyi olduklarını ifade etmişlerdir. Sadece bir öğrenci tedavi uygularken işlemin doğruluğuna dikkat etmediklerini belirtmiştir.

- Yeni yöntemlere uyum sağlamada çok kötü bir profil sergilenmiyor (24y, K, 4.ncü sinıf, Anadolu Lisesi).

- İşlerinde gerçekten yetenekliler (21y, K, 3.ncü sinıf, Düz Lise).

- $\mathrm{Bu}$ durum tamamen tecrübeye dayalı olduğundan, teknik becerileri iyi kullanmaktadırlar $(25 \mathrm{y}, \mathrm{E}$, 4.ncü sinıf, SML).

- El becerileri, yılların verdiği deneyimden dolayı çabuk müdahaleleri açısından son derece örnek davranışlar içindeler (23y, K, 4.ncü sınıf, Anadolu Lisesi)

- İşlem iyi ya da kötü bitirme telaşındalar( $21 \mathrm{y}, \mathrm{K}$, 3.ncü sinif, SML).

3.4 Tema: Bilimsel Bilgiyi ve Kongreleri Takip Etme Çalışmaya katılan öğrencilerin \%90'1 X kuşağı hemşirelerin eski bilgileriyle işlerini devam ettirdiklerini, kongrelere gitmek için vakit ayırmadıklarını, güncel bilgileri takip etmediklerini ve gelişime çok açık olmadıklarını ifade etmişlerdir. Sadece bir öğrenci genç kuşak hemşirelerin bilimsel bilgiyi takip etmede $\mathrm{X}$ kuşağına göre daha istekli olduğunu belirtmiştir.

- Eski yöntemlere bağlilar. Yenilikleri takip etmiyorlar ( 21y, K, 3.ncü sinıf, SML).

- Maalesef hemşirelerinin çoğunun 'benim bildiğim kadarı yeterli' tavrında olduğunu gözlemledim (24y, K, 4.ncü sınıf, Anadolu Lisesi).

- İş garantisini eline almış olan X kuşağ geliştirme ve kazandığı yeni bilgileri paylaşma konusunda noksandir. Bu durumun sorumlusu, her ne kadar X kuşağı olsa da, kurumların da sorumluluğu vardır (25y, E, 4.ncü sınıf, SML).

- Pek fazla bilincinde değiller. Genel olarak X kuşağı, gelişime kapalı ve gelenekçi tutum içindeler(21y, K, 3.ncü sınıf, Düz Lise).

- Çok çalıştıklarından kongrelere katılamıyorlar ancak yaşı bize daha yakın olanlar gelişime daha açıklar (21y, K, 4.ncü sınıf, Düz lise).

\subsection{Tema: Sorumluluk Bilinci}

Çalışmaya katılan öğrencilerin \%70'i hemşirelerin hastaların bakımları konusunda özellikle de tedavi saatlerine riayet ettiklerini, her hemşirenin bakım verdiği hastaların işlerini mümkün olduğunca yerine getirdiklerini ifade etmişlerdir. Bazı öğrenciler ise hemşirelerin staj sırasında hastanın tüm sorumluluğunu stajyer öğrencinin üzerine bırakmaya çalıştığını, bazıları ise hasta taşıma ve transferi sırasında hemşirelerin sorumluluklarını erkek öğrencilere yüklediklerini ifade etmişlerdir.
- Hastanın bakımına dair tedavilerini üstleniyorlar. Sorumlulukları yüksek ( 21y, K, 3.ncü sınıf, SML).

- Sorumluluk bilinçleri son derece yüksek ancak d. hastanesinde çalışan hemşireler doktor paylaşıyor. $\mathrm{Bu}$ durumda eğer ki bir doktorun hastası azsa herkes onu almak için uğraşıyor. Yani eşitsizlik ve adaletsizliğin olduğu bir düzen ortaya çıkıyor. İşin kolayına kaçmak isteyen, sorumluluk almaktan kaçan hemşirelerde mevcut $(21 \mathrm{y}, \mathrm{K}, 3$.ncü sınıf, Düz Lise).

- Profesyonelliğin getirdiklerinden dolayı, kuşak fark etmeksizin, çoğu kiși meslek sorumluluğunun bilincindedir. Özellikle tedavi saatlerine dikkat etmektedirler (25y, E, 4.ncü sınıf, SML).

- $\quad$ Erkekler öğrencilere ağırlık gerektiren hasta taşıma ve transfer işlemlerini yüklemeye çalışıyorlar, bu konuda sorumluluk almak istemiyorlar $(21 \mathrm{y}, \mathrm{E}$, 4.ncü sınıf, Anadolu Lisesi).

3.6 Tema: Eğitim Becerisi ( Hasta ve stajyer öğrencilere yönelik)

Çalışmaya katılan öğrencilerin \%70'i X kuşağ hemşirelerin hem hastayı hem de kendilerine eğitim verdiklerini ve bilgiyi aktarmada sıkıntı yaşamadıklarını ifade ederken, bir kısım öğrenci ise hastalara yeteri kadar açıklama yapmadıklarını ve yenilikleri takip ederek kendilerini eğitmeleri gerektiğini belirtmişlerdir.

- Hastayı bilgilendirip bize de öğretiyorlar (21y, K, 4.ncü sınıf, Düz lise).

- Gayet memnunum detaylı olarak her şeyi anlatıp uygulamasını gösteriyorlar $(23 \mathrm{y}, \mathrm{K}$, 4.ncü sinıf, Anadolu Lisesi)

- Bazı hemşireler hem teknik becerisi yüksek hem de eğitici yönü kuvvetli. Genel olarak anlatma ve bilgiyi aktarmada yeterliler. Başımızdaki sorumlu hemşire bize hep o klinikteki hastalığa yönelik ödevler verirdi ve biz bunlarla ilgili sunumlar yapardık. $\mathrm{Bu}$ da o hastalığı tanımamızdaki bilgi seviyemizi artırırdı (21y, K, 3.ncü sınıf, Düz Lise).

- Teknik becerisi yüksek olan X kuşağı, bu bilgileri aktarmada bir sıkıntı yaşamamaktadır (25y, E, 4.ncü sınıf, SML).

- Hastalara yeteri kadar eğitim yapmiyorlar (21y, K, 3.ncü sinıf, Düz Lise).

- Eğitim becerileri çok kötü değil fakat yeniliklere daha açık olunabilir (24y, K, 4.ncü sınıf, Anadolu Lisesi).

\subsection{Tema: Teknolojiyi Kullanma}

Çalışmaya katılan öğrencilerin tamamı (\%100) hemşirelerin teknolojik gelişmeleri takip etmemesi nedeniyle bilgisayar ya da teknik cihazları doğru bir şekilde kullanamadıklarını, staj sırasında çoğu kez bilgisayarla ilgili bir problem olduğunda öğrencilerden yardım istediklerini ifade etmişlerdir.

- Yeni olan şeylere kapalı olduklarından, buna da genel olarak yabancılar. Bilgisayarı kullanırken çoğu hemşire zorlanıyorlar. Bazen bilgisayara bir şey olunca bizden rica eden hemşireler vardı $(21 \mathrm{y}$, K, 3.ncü sınıf, Düz Lise).

- Kendi işlerini görecek kadar kullanıyorlar (21y, E, 4.ncü sınıf, Anadolu Lisesi). 
- $\quad \mathrm{X}$ kuşağı modern ve teknoloji çağının gerektirdiği yenilikleri, gerekli düzeyde takip etmemektedir. Bunun yanı sıra bunların bilincinde olmasına rağmen, kendilerini geliştirme sorumluluğunda değildirler (25y, E, 4.ncü sınıf, SML).

- Bazen bilgisayar bozulunca bize yüklüyorlar ( $21 \mathrm{y}$, K, 3.ncü sınıf, SML).

\subsection{Tema: Etik Davranıș}

Çalışmaya katılan öğrencilerin \%70'i hemşirelerin etik değerlere karşı saygılı davrandığını ve staj sırasında herhangi bir problem yaşamadıklarını ifade etmişlerdir. Öğrencilerin bir kısmı ise etik kavramının ne olduğunu bilmediklerini, hastaların ve stajyer öğrencilerin özel hayatları ve dış görünüşleriyle ilgili yorumlar yapıldığını belirtmişlerdir.

- Etik değerlere uygun davranıyorlar, hasta haklarına karşı duyarlılar (21y, K, 3.ncü sınıf, Düz Lise).

- Hastanın ve stajyerin özel hayatı, hastalığı veya diş görünüşüyle çokça dalga geçildiğine şahit oldum (24y, K, 4.ncü sınıf, Anadolu Lisesi).

- Etiğin ne olduğunu bildiklerini sanmiyorum ( 21y, K, 3.ncü sınıf, SML).

\section{Tartışma}

Kuşaklararası farklılıklar her meslek grubunu etkilediği gibi sağlık profesyonelleri içerisinde yer alan hemşirelik mesleğini de etkilemiştir [11]. Bu farklılıklar sadece hastanede çalışan hemşire grubu arasında problemlerin yaşanmasına neden olmakla kalmayıp klinik uygulamalara çıkan stajyer öğrencilerinde etkilenmesine neden olmuştur. $\mathrm{Bu}$ bağlamda $\mathrm{Y}$ kuşağı stajyer öğrencilerin klinik uygulamalar sırasında $X$ kuşağ 1 hemşirelere yönelik meslek uygulamaları adına yaşadıkları olumlu ya da olumsuz durumları belirlemek amacıyla yapılan bu çalışmada rol modeli olma, etkin iletişim, teknik beceri, bilimsel bilgiyi ve kongreleri takip etme, sorumluluk bilinci, eğitim becerisi, teknolojiyi kullanma ve etik davranış olmak üzere sekiz ayrı ortak tema belirlenmiştir.

\subsection{Tema: Rol Modeli Olma}

Öğrencilerin eğitim öğrenim sürecine katılan hemşirelerin klinikteki profesyonel davranışları ve uygulamaları kliniğin işleyişini, öğrencinin başarısını ve mesleğin statüsünü doğrudan etkilemektedir [12]. Yapılan çalışmalarda öğrencilerin kliniğe çıkmadan ve çıktıktan sonraki profesyonel algılarının değiştiği ve bunun nedeninin klinikte çalışan hemşirelerden kaynaklı olduğu saptanmıştır. $\mathrm{Bu}$ yüzden klinikte çalışan hemşirelerin öğrencilere rol model olması gerektiği ve öğrencileri hem bilgi-beceri hem de mesleki her türlü konuda desteklemeleri gerekmektedir [13-15]. Nouri ve ark. (2014) yapmış olduğu çalışmada öğrencilere sordukları 'rol model nasıl olmalıdır?' sorusuna öğrenciler, 'öğrencileri koruyan, onurlarını kırmayan ve rehberlik eden kişiler' olması gerektiği şeklinde cevap vermişlerdir [13]. Belinsky ve Tataronis (2007) ise olumlu rol model olmanın öğrencilerin performansını arttırdığını ve öğrenmesini kolaylaştırdığını saptamıştır [14]. Ryan ve McAllister (2018) hemşirelerin klinikteki rol model davranışlarını inceledikleri çalışmalarında, hemşirelerin öğrencilerin kliniğe adaptasyonu için yardım ettiği, onlara soru sormaları için teşvik ettiği, öğrencileri meslektaşları olarak gördükleri ve o şekilde öğretmeye çalıştıkları saptanmıştır [15].

Bu çalışmada da öğrencilerin bir kısmı hemşirelerin iyi bir rol model olmaya çalıştıklarını, bilgi paylaşımında bulunduklarını ifade ederken bir kısmı da öğrencilere kötü davrandıklarını ve öğretici bir yaklaşımlarının olmadığını fakat hemşirelik uygulamaları açısından rol model olabileceklerini belirtmiştir. Hemşirelerin öğrencilere öğretici tavırlarının olmaması ve öğrencileri klinik ortama oryante etmek yerine onlarla mesafeli bir ilişki yürütmeleri, klinikteki iş yoğunluğundan ve iş yüklerinden, işlerini yetiştirememe kaygılarından ve rol modeli olmayı bir görev olarak görmediklerinden kaynaklandığı düşünülmektedir.

\subsection{Tema: Etkin İletişim}

İletişim, 'kişilerin farkındalığı dışında gelişen, bireylerin davranışlarını etkileyen ve bireyler arasında bilgi, fikir, duygu ve düşünce aktarımına yardımcı olan bir süreç' olarak tanımlanmaktadır [16]. Hemşireler 24 saat kesintisiz sürmesi gereken sağlık hizmetinin en önemli parçasıdır. Bu sağlık hizmetini sürdürürken de hasta, profesyonel sağlik ekibi ve öğrenci hemşirelerle olan koordinasyonun sağlanması, klinikteki eğitimöğretim sürecinin yürütülebilmesi için etkili bir iletişim sürdürülmesi gerekmektedir [17]. Brunetto ve ark. (2012) yapmış oldukları çalışmada, kuşaklar arasındaki iletişim doyumunda anlamlı farlılıklar bulmuşlar ve kuşakların birbirleri arasında iletişim kurmakta zorlandıklarını saptamışlardır [18]. Dikmen Aydın ve ark. (2017) çalışmalarında hemşirelerin öğrencilerle iletişim düzeylerinin \%67.'1 ile orta düzeyde olduğunu belirtmişlerdir [19]. Karadağ ve ark. (2013) yapmış oldukları çalışmada ise öğrencilere klinik uygulamanın ilk gününde hemşirelerden beklentilerinin ne olduğu sorulduğunda \%16.5'i 'iyi iletişim kurabilmeleri' şeklinde cevap verdikleri belirlenmiştir [20]. Yapılan çalışmalarda klinik hemşireleri ile iletişim problem yaşayan öğrencilerin üzüntü, huzursuzluk, öfke, çalışma isteksizliği, kendini değersiz hissetme, okuduğu bölümü değiştirmek isteme gibi olumsuz duygular yaşayabileceği ifade edilmektedir [21]. Bu çalışmada da öğrenciler, X kuşağı hemşirelerin etkin bir şekilde iletişim kurmadıklarını, şive farklılığı nedeniyle anlaşmada zorlandıklarını, hastalarla çok efektif olmasa da bir şekilde iletişim kurduklarını ancak öğrencilerle mesafeli olduklarını belirtmişlerdir. Bunun nedeninin hemşirelerin kuşaklararası farklılıklarının yanı sıra, eğitim düzeyleri ve şive farklılıkları sebebiyle de geliştiği düşünülmektedir.

\subsection{Tema: Teknik Beceri}

Günümüzde, hastaların hastanede yatış süresinin kısaltılmak istenmesi, sağlık bakım hizmetlerindeki modernleşme ve sağlık bakım maliyetlerinin etkin bir biçimde kullanılmak arzusu, uzmanlaşmış yüksek beceri sahibi olan hemşirelere olan ihtiyacı giderek arttırmıştır. $\mathrm{Bu}$ modernleșme beraberinde sağlık bakım hizmetlerinin liberalleşmesi ile sonuçlanmıştır. Bununla 
birlikte hemşirelik uygulamalarının bilimsel temelli, etkin maliyetli, daha kompleks bir hal alması da hemşirelere düşen görev ve sorumluluklarında artmasına neden olmuştur [22-23]. Ayrıca bu durum ilerledikçe hemşirelerin kariyer gelişimi ihtiyaçlarında da bir artış gündeme gelmiş ve beceri gelişiminin zorunlu kılmıştır. Gelişmiş klinik beceri zorunluluğu beraberinde bilimsel gelişmeleri ve hasta bakım kalitesinde bir artışı gündeme getirmiştir. Eyi ve ark. (2016) hastaların hemşirelik becerilerini değerlendirdiği çalışmasında, hastaların hemşirelerin teknik becerilerini yüksek bulduğu ve bundan memnun oldukları belirlenmiştir [24]. Eker ve ark. (2014) yapmış olduğu çalışmada ise öğrencilerin eğitmenlerinin teknik becerisini yüksek bulduğu ve teknik becerisi yüksek olan eğitmenlerin öğrencileri daha çok motive ettiği ve öğrenme isteği uyandırdığ 1 saptanmıştır [25]. Bu çalışmada da Y kuşağı öğrenciler, X kuşağı hemşirelerin yılların verdiği birikim nedeniyle teknik becerilerini yüksek bulduklarını belirtmişlerdir.

\subsection{Tema: Bilimsel Bilgiyi ve Kongreleri Takip Etme}

Hemşirelik mesleğinde profesyonel kimlik oluşturabilmede şüphesiz bilimi, bilimsel bilgiyi ve bilimsel yöntemi yeteri derecede anlamak ve o bilgiyi mesleği uygulamalara entegre etmek gerekmektedir [26].

$\mathrm{Bu}$ açıdan, bilimsel yöntemler kullanılarak yapılan çalışmalar ilerde hemşirelik mesleğinin otonomisini arttıracak ve mesleki karar verme olgusunu güçlendirecektir. Ayrıca hemşirelik mesleğine mensup bireyleri örtük bilgiden kanıta dayalı bilimsel bilgi ile verilmiş kararları alabilecek düzeye getirmiş olur ve bir süre sonra bilimsel bilgiyi kullanarak kendi bilgisini üretecek konumda olan bir meslek olmanın hızını arttıracağ1 düşünülmektedir. Bu yüzden klinikte çalışan hemşirelerin bilimsel bilgiyi takip etmeleri ve uygulamalarına yansıtmaları profesyonel kimlik açısından hayati önem taşımaktadır [27]. Aydın ve ark. (2015) hemşire ve ebelerin bilimsel bilgiyi kullanım tutumlarını inceleyen çalışmasında, hemşire ve ebelerin \%70' inin bilimsel toplantılara katıldıkları ve bilimsel çalışmalardan yararlanma oranlarının \%82.8 olduğu saptanmıştır [28]. Bununla birlikte Emiroğlu ve arkadaşlarının çalışmasında ise hemşirelerin \%49,8'inin hemşirelik uygulamalarında yeni yapılan güncel araştırmalardan yararlandığı ve \%83.7' toplantılara katıldıkları saptanmıştır [29]. Happel ve ark. (2003) çalışmasında da mesleki yayın takip etme oranı \%62 olarak bulunmuştur [30]. Bu verilerin ulusal alan yazınla paralellik gösterdiği fakat yurtdış1 oranlarıyla farklılık gösterdiği görülmüştür. $\mathrm{Bu}$ farklılığın yurt dişındaki bilimsel yayınları okuma kültürünün Avrupa'da yaygın olmasından kaynaklı olduğu düşünülmektedir. Bu çalışmada da öğrenciler, $\mathrm{X}$ kuşağı hemşirelerin bilimsel yayınları ve kongreleri takip etmediklerini ve yeniliklere çok açık olmadıklarını belirtmişlerdir. Bunun nedeni, kuşak özelliklerinden kaynaklanmasının yanı sıra hemşirelerin çalışma saatlerinin yoğunluğu, hemşire başına düşen hasta sayısının fazlalığı, bilimsel çalışma yapma ve kongrelere katılma konusunda motivasyon kaynaklarının olmayışı olabilir.

\subsection{Tema: Sorumluluk Bilinci}

Bilim ve teknolojinin hızla gelişmesi insan yaşamının her yerinde nitelikli insan kaynaklarına olan ihtiyacı arttırmıştır. Bu gelişme insanoğlunu; kendini iyi tanıyan, sorumlulukları konusunda bilinçli, kişisel gelişmeyi önemseyen, düşünen, sorgulayan, araştıran, akılcı kararlar alan, kendileriyle ilgili gelişmelerin ve tartışmaların dışında kalmayan bir birey haline getirmiştir [31]. $\mathrm{Bu}$ gelişmeler sonucu akademik ortamda ve klinikte çalışan hemşirelerin sorumlulukları artmakta ve hemşirelik hizmetlerini dinamikleştirmektedir. $\mathrm{Bu}$ sorumluluklar kişilerin felsefelerini hemşirelik felsefesine uyarlayarak, mesleki eğitimle edindiği bilimsel bilgileri, becerilerini yerine getirerek gerçekleştirilmiş olur [32]. Bununla birlikte her kuşağın sorumluluk bilincinin farklı olduğu ve sorumluluklarını yerine getirme duygularının farklı olduğu da bilinmektedir [3]. Yapılan çalışmalar incelendiğinde Yetim ve Beydağ 'in (2015) çalışmasında hemşirelerin aktiviteleri incelenmiş ve hemşirelerin sorumluluklarını orta seviyede yerine getirdikleri saptanmıştır [33]. Başka bir çalışmada ise yoğun bakım hemşirelerinin bakım sorumluluklarını yerine getirme düzeylerinin orta seviyede olduğu belirlenmiştir [34]. Bu çalışmada öğrencilerin büyük bir çoğunluğu X kuşağı hemşirelerin sorumluluk bilincinin yüksek olduğunu ve özellikle hastaların tedavi rutinlerine riayet ettiklerini belirtmişlerdir. Bu bağlamda kuşaklar arasında sorumluluk bilincinin aktarımının mesleki gelecek açısından önemli olduğu düşünülmektedir.

\subsection{Tema: Eğitim Becerisi}

Sağlıkta eğitim faaliyetleri ve hasta eğitimi ilk defa 1950 yıllarında ortaya çıkmış ve başlangıç noktası olmuştur. Sağlık eğitimi, ilk yıllarda koruyucu sağlık hizmetleri kapsamında kullanılmaya başlanmış daha sonraki yıllarda teknolojinin gelişmesi ile sağlığın korunması, geliştirilmesi ve mevcut sağlık durumu ile baş edebilmek amacıyla kullanılmıştır [35]. Hemşirelerin hasta ve hasta yakınlarıyla en çok iletişimde olan ve onlarla en çok vakit geçiren sağlık disiplini üyesi olduğu bilinmektedir. Bireyin ve toplumun sağlığını korumak, geliştirmek ve hastalık halinde iyileştirmeye yönelik doğru sağlık davranışları kazandırmak hemşireliğin temel eğitici rolüdür [36]. Son yıllarda hasta eğitiminin önemi maliyet açısından değerlendirilmiş ve nitelikli hemşireler tarafından verilen eğitimin maliyeti önemli ölçüde düşürdüğü, hasta eğitiminin hasta memnuniyetini arttırdığı ve hastaneye geri dönüşleri azalttığı saptanmıştır [37].

Klinik hemşirelerinin eğitici rolü sadece hastalara değil, aynı zamanda staj uygulamalarına gelen öğrencilere de yöneliktir. Akgün Kostak ve ark. (2012) yaptığ çalışmada öğrencilerin \%53,9'u servis hemşirelerinin eğitimlerinde sorumlu olduklarını, Akyüz ve ark (2007) ise klinik hemşirelerinin öğrencilerin eğitiminde kendilerini dersin sorumlu öğretim elemanı ve klinik 
sorumlu hemşiresinden sonra sorumlu olarak gördüklerini belirtmişlerdir [38-39]. Bu çalışmada da öğrencilerin büyük çoğunluğu X kuşağı hemşirelerin hem hastalara hem de kendilerine eğitim verdiklerini ve bilgi aktarımında bir problem yaşamadıklarını belirtmişlerdir.

\subsection{Tema: Teknolojiyi Kullanma}

Bilgisayar teknolojilerinin gelişimi, modern tıpta, tanı, tedavi ve bakıma yönelik ekstrem katkılar sağlamakta ve sağlık bakım hizmetleri sunumuna önemli ölçüde hız kazandırmaktadır. Bununla birlikte sağlık bakım hizmetleri maliyetini azaltarak, bu hizmetin en etkin biçimde sunulmasını sağlamaktadır [40]. Günümüzde bilgisayar ve bilişim teknolojisindeki gelişim ile sağllk disiplinlerinde ve özellikle hemşirelik mesleğinde önemli ölçüde gelişmeler ve değişimler meydana gelmiştir [41]. Bilgisayarın hemşirelik hizmetleri alanında kullanımı ile hemşirelik sürecinin bilgisayar ortamına aktarılmasını, hasta bilgilerine kolay erişimi, eğitimin planlanmasını, diğer sağlık profesyonelleriyle bilgi paylaşımını, zamandan tasarrufu ve kırtasiyecilik yükünün azalması sağlanmaktadır [42]. Hemşirelerin bilgisayar teknolojilerini kullanma durumunu belirlemek amacıyla yapılan çalışmalarda; Köse \%32,9, Softa ve ark. \%36,3, Kaya ve ark. \%80, Başar ve ark. çalışmasında ise \%1.4 olarak bildirilmektedir [40, 41, $43,44]$.

$\mathrm{Bu}$ oranlara bakıldığında bilgisayar ve bilişim teknolojilerinin hemşireler tarafindan etkin kullanılmadığı görülmektedir. $\mathrm{Bu}$ çalışmada da öğrenciler, X kuşağı hemşirelerin teknolojiyi kullanmada problem yaşadıklarını ve bilgisayarla ilgili bir problem yaşandığında çoğu kez kendilerinden yardım istediklerini belirtmişlerdir. Bilgisayar kullanımının hasta bakımı ve sağlık hizmetlerinde ilerleyen yıllarda daha çok artacağı ve hemşirelik biliminin geride kalmaması adına teknolojiye daha çok adapte olmaları ve teknolojiyi daha etkin kullanmaları gerektiği düşünülmektedir.

\subsection{Tema: Etik Davranıș}

Toplumsal değişimlerin ve globalleşmenin hızla yaşandığ1 günümüz dünyasında etik ilkelere ve değerlere olan ihtiyaç giderek artmakta ancak yaşanan gelişmeler bir dizi etik sorunlarında ortaya çıkmasına zemin hazırlamıştır [45]. Sağlık disiplinleri içerisinde hastalarla sürekli diyalog halinde olan, bakım ve tedavinin temel unsuru olan hemşireler, artan rol ve sorumlulukları gereği çoğu zaman çözümlemekte zorlandıkları etik sorunlarla yüzleşmek zorunda kalmaktadırlar. Alanyazına bakıldığında hemşirelerin daha çok hastanın bakımı konusunda diğer sağlık ekibiyle anlaşamaması, hasta haklarının korunması, bilgilendirilmiş onam alımı, terminal dönemdeki hastanın bakımı, ekip üyelerinin etik dışı davranışları konusunda sorun yaşadıkları ifade edilmektedir. $\mathrm{Bu}$ problemlerin çözümünde ise hemşirelerin etik duyarlılıklarının yüksek olması gerekmektedir [46]. Bu sorunlar karşısında hemşirelerin oluşturacakları etik davranış, bireysel özellikler, değer ve tutumlara göre şekil almaktadır. ABD’de 2008 yılında 1010 kişi ile mesleki dürüstlük ile ilgili yapılan kamuoyu yoklamasında, katılımcıların $\% 85$ 'i hemşirelerin dürüst olduğunu ve etik standartları yüksek ya da çok yüksek düzeyde değerlendirmiştir [47]. Hemşirelerin etik duyarlılıklarını belirlemek amacıyla yapılan bir çalışma ise hemşirelerin etik konularını eğitimleri sırasında gördüğü ve bilgi sahibi olduğu, yaş faktörünün etik duyarlılığı azalttığı saptanmıştır [48]. Bu sonuç bizlere kuşaklararası farklılı̆̆ın etik duyarlılık ve davranışlarını etkileyen bir değişken olduğunu göstermektedir. Kahriman ve Yeşilçiçek Çalık (2017) tarafından yapılan çalışmada hemşirelerin etik duyarlılıklarının yüksek olduğu, Filizöz ve ark (2015) çalışmasında ise orta düzeyde olduğu belirlenmiştir [46, 49]. Firat ve ark. (2017) çalışmasında acil servis hemşirelerinin etik duyarlılıklarının orta düzeyde olduğu ve etik eğitimi almalarına rağmen çoğunluğunun yaşadıkları etik sorunları çözemedikleri belirlenmiştir [50]. Bu çalışmada öğrencilerin çoğunluğu staj uygulamaları sırasında herhangi bir etik sorunla karşılaşmadıklarını, uygulamalarda etik ilkelere özen gösterdiklerini, bir kısmı ise eriğin anlamını bilmediklerini belirtmiştir. $\mathrm{Bu}$ sonuçlar literatürle benzerlik göstermektedir.

\section{Sonuç}

Çalışmanın sonucunda, Y kuşağı stajyer öğrencilerin X kuşağı çalışan hemşirelere karşı rol modeli oldukları ancak erkek hemşirelere yönelik cinsiyet ayrımcılığ uyguladıkları, hasta-hemşire ve stajyer öğrenci-hemşire arasındaki iletişimi yetersiz buldukları, teknik becerilerinin iyi olduğu ancak bazılarının hem stajyer öğrenci eğitimlerinde hem de hasta eğitimlerinde yetersiz oldukları, bilimsel bilgiyi ve kongreleri takip etmedikleri, sorumluluk bilinçlerinin yüksek olduğu ama bazı hemşirelerin hastaların sorumluluklarını tümüyle öğrenciye vermek istedikleri, teknolojiyi kullanamadıkları ve bazı hemşirelerin etik kavramının anlamını bilmedikleri ve etik konularda özensiz oldukları tespit edilmiştir.

- $\mathrm{Bu}$ eksikliklerin giderilmesi amacıyla hemşirelik mesleğinde cinsiyette denge sağlamak ve hemşirelik imajını geliştirmek için erkek öğrencilerin öğretim elemanları tarafından klinik uygulamalarda desteklenerek, klinik hemşireleri, hasta ve yakınlarına geleceğin hemşirelik mesleğini yapacak bireyler arasında erkeklerinde yer alacağı ve mesleğe olumlu katkılarının olacağı konusunda bilgilendirmelerin yapılması ve meslekte kabul görmelerinin sağlanması,

- Klinik hemşirelerinin erkek hemşire öğrencilere karşı cinsiyet ayrımcılığı yapma nedenlerinin araştırılması ve ortaya konan nedenlere yönelik hizmet içi eğitim programlarında cinsiyet ayrımcılığını önleme ile ilgili eğitimlerin verilmesi ve öğretim elemanları ile birlikte çözüm önerilerinin sunulmas1,

- Klinik hemşirelerinin hasta-hemşire ve stajyer öğrenci-hemşire arasındaki sözlü/sözsüz iletişimi ve empati düzeylerini arttırmak amaçlı hizmet içi 
eğitim programlarında iletişim ve empati ile ilgili konulara daha çok yer verilmesi, vakalar üzerinde rol-play uygulaması yaptırılması ve bu eğitimlerin belirli aralıklarla tekrarlatılması,

- Klinik hemşirelerinin stajyer öğrencilerin eğitimlerine katkı sağlamaları için öğretim elemanları tarafından hemşirelere koçluk eğitimlerinin verilmesi ve klinik hemșireler ile stajyer öğrencilerin staj uygulamaları sırasındaki beklentilerinin belirlenmesi,

- Klinik hemşirelerinin hasta eğitimleri için stajyer öğrencilerle birlikte eğitimler planlaması, eğitimlere hasta yakınlarının da dahil etmesi, eğitimler sırasında hastaların durumlarına göre görsel materyal kullanması ve uygulamalı göstermesi,

- Klinik hemşireleri tarafından stajyer öğrencilere yönelik klinik işleyişte ve hasta bakımı konularında görev dağılımlarının yapılmasının sağlanarak uygulamalarla ilgili tüm sorumluluğun öğrencilere yüklenmemesi,

- Klinik hemşirelerinin bilimsel bilgiyi ve kongreleri takip etmesi için hastane yönetimi tarafından bilgilendirmelerin yapılması, kongreye gitmeleri konusunda teşvik edilmesi ve maddi olarak imkan sağlanması,

- Klinik hemşirelerinin yeni teknolojiye uyumunun arttırılması için hizmet içi eğitim faaliyetlerinin ve sertifika programlarının oluşturulması ve elektronik sağlık kayıtlarının kullanımı konusunda farkındalık arttırılması,

- Klinik hemşirelerinin etik davranışlarını olumlu yönde arttırmak amaçlı hizmet içi eğitimlerin verilmesi, vaka çalışmaları ile rol-play yapılarak oluşabilecek etik hatalar konusunda farkındalık oluşturulması, hastane yönetimi tarafından da oluşabilecek etik sorunlara yönelik önleyici faaliyetler geliştirilmesi,

- Öğrencilerin klinik uygulamada yaşadığı güçlükleri öğretim elemanlarıyla paylaşması için uygun ortamın sağlanması, düzenli olarak klinik hemşireleri ile toplantılar yapılarak öğrencilerle yaşanan sorunlar ve çözüm önerilerine yönelik paylaşımlar yapılması önerilebilir.

\section{Kaynaklar}

1. Türk Dil Kurumu (TDK), Büyük Türkçe Sözlük, http://www.tdk.gov.tr/index.php?option=com_bts\&vie $\mathrm{w}=\mathrm{bts}$ (accessed 19.05.2018).

2. Lavoie-Tremblay M, Marchionni M. The needs and expectations of generation Y nurses in the workplace. J Nurses Staff Dev. 2010;26(1): 2-8.

3. Metin, S, Kızıldağ, D. X ve kuşaklarının kariyer beklentilerinin farklılaşması: Otomotiv sektöründe bir araştırma. Mustafa Kemal Üniversitesi Sosyal Bilimler Enstitüsü Dergisi. 2017;14(40):340-363.

4. Christensen, SS, Wilson, BL, Edelman, LS. Can I relate? A review and guide for nurse managers in leading generations. J Nurs Manag. 2018:26:689-695.

5. Wiedmer, T. Generations do differ: Best practices in leading traditionalists, boomers, and generations $\mathrm{X}, \mathrm{Y}$, and Z. Delta Kappa Gamma Bulletin. 2015;82(1):5157.
6. Haydar,i SM, Kocaman, G, Tokat, MA. Farklı kuşaklardaki hemşirelerin işten ve meslekten ayrılma niyetleri ile örgütsel ve mesleki bağll1/klarının incelenmesi. SHYD. 2013;3(3):119-131.

7. Saraçel, N, Taşseven, Ö, Kaynak E. Türkiye'de çalışan $\mathrm{Y}$ kusağında is tatmini-motivasyon iliskisi. Social Sciences Research Journal. 2016;5(1):50-79.

8. Stanley, D. Multigenerational workforce issues and their implications for leadership in nursing. J Nurs Manag. 2010;18(7):846-852.

9. Joseph, ML. Innovativeness in nursing: A phenomenological and constructivist study. Dissertation, Capella University, Minneapolis, Minnesota, 2007.

10. Jolley, J. Hemşirelik ve sağlık profesyonelleri için araştırma ve kanıta dayalı uygulamaya giriş. 2. bask1. Ankara: Nobel Yayıncilık, 2014.

11. Başoğlu, M, Durmaz EA. X ve $\mathrm{Y}$ kuşağındaki hemşirelerin ve hemşirelik öğrencilerinin bireysel yenilikçilik farkındalıklarının karşılaştırılması. GÜSBD. 2017;6(4):77-84.

12. Ünsal, A, Gözüm, S, Koçak, D, İpek, G, Uygur H. Klinik hemșire gözüyle öğrenci hemșireler. Atatürk Üniversitesi Hemşirelik Yüksekokulu Dergisi. 2002;5(2):29-38.

13. Nouri, JM, Ebadi, A, Alhani F, Rejeh N. Experiences of role model instructors and nursing students about facilitator factors of role-modeling process: A qualitative research. Iran J Nurs Midwifery Res. 2014;19(3):248-254.

14. Belinsky, S, Tataroni, G. Past experiences of the clinical instructor and current attitudes toward evaluation of students. J Allied Health. 2007;36(1):1117.

15. Ryan, C, McAllister M. The experiences of clinical facilitators working with nursing students in Australia: An interpretive description. Collegian. 2018;544(7): 17.

16. Başar, G, Akın, S, Durna, Z. Hemşirelerde ve hemşirelik ögrencilerinde problem çözme ve iletişim becerilerinin değerlendirilmesi. GÜSBD 2015;4(1):125-147.

17. Yalçın, B, Tetik, S, Açıkgöz, A. Yüksekokul öğrencilerinin problem çözme becerisi algıları ile kontrol odağı düzeylerinin belirlenmesine yönelik bir araștırma. OYBD. 2010;2(2):19-27.

18. Brunetto, Y, Wharton F, Shacklock K. Communication, training, well-being, and commitment across nurse generations. Nurs Outlook. 2012;60:7-15.

19. Dikmen Aydın Y, Şahin Orak N, Gürkan A, Aslan G, Demir F. Hemșirelik öğrencilerinin klinik eğitimleri sırasında hemşirelerden aldığı desteğin değerlendirilmesi. JAREN. 2017;3(3):109-115.

20. Karadă̆, G, Parlar, Kılıç S, Ovayolu N, Ovayolu Ö, Kayaaslan H. Öğrenci hemşirelerin klinik uygulamada karșlaștıkları güçükler ve klinik hemșireler hakkındaki görüşleri. TAF Prev Med Bull. 2013;12(6):665-672.

21. Gözüm S, Ünsal A, Kaya A, Ünlü F. Hemșirelik öğrencilerinin gözüyle klinik hemşireleri. Atatürk Üniversitesi Hemşirelik Yüksekokulu Dergisi. 2000;3(1):29-35

22. Fairbrother G, Jones A, Rivas K. Changing model of nursing care from individual patient allocation to team nursing in the acute inpatient environment. Contemp Nurse. 2010;35(2):202-220.

23. Cioffi J, Ferguson L. Team nursing in acute care settings; Nurses' experiences. Contemp Nurse. 2009;33(1):2-12

24. Eyi, S, Kanan, N, Akyolcu N, Akın LM, Acaroğlu R. Ameliyat sırasında uygulanan hemșirelik bakımının hastalar tarafindan değerlendirilmesi. TAF Prev Med Bull. 2016;15(2):159-169.

25. Eker F, Aç̣ıgöz F, Karaca A. Hemşirelik öğrencileri gözüyle mesleki beceri eğitimi. DEUHEFED. 2014;7(4):291-294. 
26. Copur, Ö.E, Kuru, N, Seymen, CÇ. Hemşirelikte kanıta dayalı uygulamalara genel bakış. Sağlık ve Hemşirelik Yönetimi Dergisi. 2015;1(2): 51-55.

27. Karagözoğlu, Ş. Bilim, bilimsel araştırma süreci ve hemşirelik. Hacettepe Üniversitesi Hemşirelik Yüksekokulu Dergisi. 2006;13(2):64-71

28. Aydın, Y, Adıgüzel, A, Topal AE. Ebe ve hemşirelerin bilimsel çalışmalara yönelik tutumlarının belirlenmesi. J Hum Rhythm. 2015;1(4):168-175.

29. Emiroğlu, ON, Ünlü, H, Terzioğlu, F, Bulut H Hemsirelerin araștırmalara katılma durumları, araştırmaya ilişkin görüşleri ve bilgi gereksinimleri. Hemşirelikte Araştırma Geliştirme Dergisi. 2005;5(1):64-86.

30. Happel, B, Johnson, L, Hill C. İmplementing research finding into mental nursing practice: Exploring the clinical research fellowship approach. J Adv Nurs. 2003;12(4):251-258.

31. İskender, DM, Karadağ, A. Hemșirelik son sinıf öğrencilerinin eleştirel düşünme düzeylerinin belirlenmesi. DEUHEFED. 2015;8(1):3-11.

32. Aştı T, Acaroğlu R Hemşirelikte sık karşılaşılan hatal uygulamalar. C.Ü. Hemşirelik Yüksekokulu Dergisi. 2000;4(2):22-27.

33. Yetim, S, Beydağ, DK. Nazilli devlet hastanesinde çalısan hemsirelerin mesleki otonomileri ve etkileyen faktörler. Sağlık ve Hemşirelik Yönetimi Dergisi. 2015;2(2):62-69.

34. Kangallı, P. Sivas ili hastanelerinde çalıșan hemşirelerin otonomi düzeyleri ve otonomiyi etkileyen mesleki ve kurumsal faktörlerin incelenmesi. Cumhuriyet Üniversitesi Sağlık Bilimleri Enstitüsü. Yüksek Lisans Tezi, Sivas, 2005.

35. Cook DA, Hatala R, Brydges R, et al. Technologyenhanced simulation for health professions education A systematic review and meta-analysis. JAMA 2011;306:978-88.

36. Aydemir, Gedük E. Hemşirelik mesleğinin gelișen rolleri. HSP. 2018;5(2):253-258

37. Zendejas B, Wang TA, Ryan B, Hamstra JS, Cook D Cost: The missing outcome in simulation-based medical education research: A systematic review. Surgery. 2013;153(2):160-173.

38. Akgün Kostak M, Aras T, Akarsu Ö. Hemșirelik öğrencilerinin klinik hemşirelerin eğitimlerine verdiği katkıya ilişkin görüşleri. Cumhuriyet Hem Der 2012;2:39-46

39. Akyüz, A, Tosun, N, Yıldız, D, Kılıç A. Klinik öğretimde hemşirelerin, kendi sorumluluklarına ve hemşirelik öğrencilerinin çalışma sistemine ilişkin görüşleri. Kor Hek. 2007;6(6):459-464.

40. Köse, A. Hemşirelerin bilgisayar kullanım durumlarının belirlenmesine yönelik bir ampirik çalıșma. Trabzon ili örneği. BTD. 2012;5(1): 37-43.

41. Softa KH, Akduran F, Akyazı E. Hemşirelerin bilgisayar kullanımlarına yönelik tutumlarının değerlendirilmesi. GÜSBD. 2014;3(3):845-858.

42. Özkul Özel H, Özdemir Ürkmez D, Demiray S, Cebeci Z. Nursing informatics and hospital management system. Eur Arch Med Res. 2014;30(3): 158-160.

43. Kaya N, Aștı T, Kaya H, Kaçar YG. Hemșirelerin bilgisayar kullanımına ilişkin görüşlerinin belirlenmesi. İ.Ü.F.N Hemşirelik Yüksekokulu Dergisi. 2008;16(62): 83-89.

44. Başar, A, Delice T, İlhan N, Ergün MA, Soncul H Hemşirelik hizmetlerinde bilgisayar kullanımı - Gazi üniversitesi tıp fakültesi hastanesi örneği. BTD. 2008;1(1): 43-46

45. Büyükkoçak, Ü, Çakırca M. Anestezi ve yoğun bakım ile ilgili etik konular. Turkiye Klinikleri J Anest Reanim. 2007;5:19-30.

46. Kahriman, İ, Yeşilçiçek Çalık K. Klinik hemşirelerin etik duyarlılığ1. GÜSBD. 2017;6(3):111-121.

47. Bednarski D. The value of nursing. Nephrol Nurs $\mathbf{J}$ 2009;36(2):115-117.

48. Başak, T, Uzun S, Arslan F. Yoğun bakım hemsirelerinin etik duyarlılıklarının incelenmesi. Gulhane Med J. 2010;52:76-81.

49. Filizöz, B, Așçı A, Mesci G. Bağçıvan E Hemşirelerde etik duyarlılık: Sivas ili merkez kamu hastanelerinde bir araştırma. İş Ahlakı Dergisi. 2015;8(1):47-66

50. Fırat, B, Karataş, G, Barut, A, Metin G, Sarı D. Acil servis hemșirelerinin etik duyarlılıklarının incelenmesi. DEUHFED. 2017;10(4):229-235.

http://edergi.cbu.edu.tr/ojs/index.php/cbusbed isimli yazarın CBU-SBED başlıklı eseri bu Creative Commons Alıntı-Gayriticari4.0 Uluslararası Lisansı ile lisanslanmıştır.

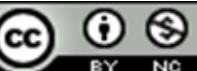

